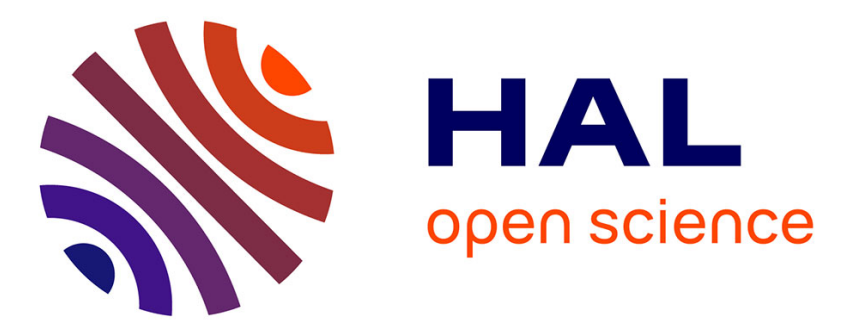

\title{
High-Frequency Dielectrophoresis Characterization of Differentiated vs Undifferentiated Medulloblastoma Cells
}

\author{
Rémi Manczak, Sofiane Saada, Mirella Tanori, Arianna Casciati, Claire \\ Dalmay, Barbara Bessette, Gaëlle Bégaud, Serge Battu, Pierre Blondy, Marie \\ Odile Jauberteau, et al.
}

\section{To cite this version:}

Rémi Manczak, Sofiane Saada, Mirella Tanori, Arianna Casciati, Claire Dalmay, et al.. HighFrequency Dielectrophoresis Characterization of Differentiated vs Undifferentiated Medulloblastoma Cells. IEEE Xplore Digital Library, 2018, pp.1-2. 10.23919/EMF-MED.2018.8526006 . hal01975348

\section{HAL Id: hal-01975348 \\ https://hal-unilim.archives-ouvertes.fr/hal-01975348}

Submitted on 22 Jan 2019

HAL is a multi-disciplinary open access archive for the deposit and dissemination of scientific research documents, whether they are published or not. The documents may come from teaching and research institutions in France or abroad, or from public or private research centers.
L'archive ouverte pluridisciplinaire HAL, est destinée au dépôt et à la diffusion de documents scientifiques de niveau recherche, publiés ou non, émanant des établissements d'enseignement et de recherche français ou étrangers, des laboratoires publics ou privés. 


\title{
High-Frequency Dielectrophoresis Characterization of Differentiated vs Undifferentiated Medulloblastoma Cells
}

\author{
Rémi Manczak $^{1}$, Sofiane Saada ${ }^{2}$, Mirella Tanori ${ }^{3}$, Arianna Casciati ${ }^{3}$, Claire Dalmay ${ }^{1}$, Barbara Bessette ${ }^{2}$, Gaelle \\ Begaud $^{2}$, Serge Battu ${ }^{2}$, Pierre Blondy ${ }^{1}$, Marie Odile Jauberteau ${ }^{2}$, Canan Baristiran Kaynak ${ }^{4}$, Mehmet Kaynak ${ }^{4}$, \\ Cristiano Palego ${ }^{5}$, Caterina Merla ${ }^{3}$, Barbara Tanno ${ }^{3}$, Mariateresa Mancuso ${ }^{3}$, Fabrice Lalloué ${ }^{2}$, Arnaud Pothier $^{1}$ \\ ${ }^{1}$ XLIM-UMR 7252, University of Limoges/CNRS, Limoges, France, pothier@xlim.fr \\ ${ }^{2}$ CAPTuR-EA 3842, University of Limoges, Limoges, France, fabrice.lalloue@unilim.fr \\ ${ }^{3}$ ENEA, SSPT - Division of Health Protection Technologies, Rome, Italy, mariateresa.mancuso@enea.it \\ ${ }^{4}$ IHP, Frankfurt (Oder), Germany, baristiran@ihp-microelectronics.com \\ ${ }^{5}$ Bangor University, Bangor, United Kingdom, c.palego@bangor.ac.uk
}

\begin{abstract}
This paper introduces first results of characterization of medullobastoma cell lines using high frequency dielectrophoresis (HF-DEP) approach at frequencies ranging up to few hundreds of MHz. Such technique enables accessing intracellular dielectric property specificities on individual cells. Actually, the frequency dependent DEP behavior of several medullobastoma cells has been studied showing clear differences between cells from different types which correlate well the biological specificity established though cell phenotype characterization. These results should pave the way to novel and complementary cell discrimination approach based on a label free HF-DEP crossover frequency signature measurement.
\end{abstract}

Keywords-HF dielectrophoresis; dielectric spectroscopy; cell discrimination; differentiated vs undifferentiated cells

\section{INTRODUCTION}

Medullobastoma (MB) is one of the most frequent pediatric malignant brain tumors, commonly found in children between ages of three and ten. Treatments for MB tumors usually include surgery followed by radiation and/or chemotherapy, leading to a 5-year survival rate of $70 \%$ to $80 \%$ for low-grade tumor that falls down to $60 \%$ if tumor has spread to the spinal cord and even decreases down to $30-50 \%$ for youngest patients (less than 3 years old) with very aggressive tumor. Especially for most aggressive cases, the tumor presents a stronger resistance to existing treatments that implies a lower therapy efficiency and a tumor relapse. Actually, the role of undifferentiated cells in such resistance is still under investigation, especially for cancerous stem cells (CSC) known to be some of tumor initiating cells. Currently, characterization of the CSC populations is based on targeting a set of biological markers to validate the stemness lineage of the cancer cells from the heterogenic cell population making the tumor.

Complementary to biological specifies of such undifferentiated cells, their proper physical characteristics and especially the dielectric properties of their intracellular content can be another way to identify and discriminate them from other differentiated. For example, dielectrophoresis (DEP) is a label-free, accurate, fast, and low-cost diagnosis technique that uses the principle of polarization and motion of bio-particles submitted to electric fields. Its efficiency has been proved in various fields and its use for medical research is promising [2].

In this article, we present the results of DEP characterizations led on different $\mathrm{MB}$ cells cultured in such way to favor differentiated and undifferentiated (large enrichment) cell grown. The achieved experiments have consisted in accurately measuring the DEP HF crossover frequency: the transition frequency from positive to negative DEP behavior that occurs here for frequencies above tens of $\mathrm{MHz}$ contrary to commonly exploited LF (low frequency) crossover measured in the hundreds of $\mathrm{kHz}$ regime. These measurements have been led on individual cells coming from two different cell lines both cultured under two different differentiation conditions. Such measurements constitute a representative DEP signature that appeared to be well correlated to cell own biological specificities.

\section{MATERIALS AND MethodS}

\section{A. Cell crossover frequency measurement measurment}

The same methodology introduced in [3-4] has been used for measuring HF crossover frequency of selected MB cells. Figure 1 illustrates typical DEP cell signature observed at HF frequencies associated with the trapped cell location on sensor.

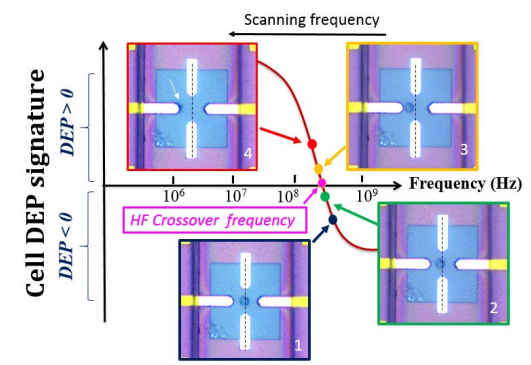

Fig. 1. Cell HF-DEP signature \& HF crossover frequency measurement. 
As shown, a quadrupole microelectrode sensor implemented in a microfluidic channel has been used to allow individual cell electromanipulation and selective DEP characterization.

High frequency signals, ranging from $50-350 \mathrm{MHz}$, have been used to probe the dielectric content of the cell cytoplasm bypassing the plasma membrane and offering unique capabilities to investigate the intracellular dielectric properties. According to the applied frequency, cell can be then individually electromanipulated by negative (Neg) DEP force (so repealed in the center of the quadrupole) or by positive DEP force (attracted on the edge of one of lateral electrode). The crossover frequency occurs when the cell passes from one DEP behavior to the other and it can be detected starting from Neg-DEP state and decreasing the applied signal frequency by $1 \mathrm{MHz}$ step until observing the cell displacement from position 2 to 3 as illustrated in Fig. 1.

\section{B. Cell preparation}

Experiments were performed on D341 and D283 cell lines from ATCC resource bank, both line derived from malignant child patient medullosblastoma. These cells were seeded in appropriate flasks at $5 \times 10^{5}$ viable cells $/ \mathrm{ml}$ and cultured at $37^{\circ} \mathrm{C}$ in a humidified $5 \% \mathrm{CO} 2-95 \%$ air incubator in two different ways: Differentiated cells were cultured in a Normal medium: Eagle's Minimum Essential Medium (MEM) supplemented with $10 \% \mathrm{FBS}, 2 \mathrm{mM}$ glutamine and $100 \mathrm{U}$ penicillin and $0.1 \mathrm{mg} / \mathrm{mL}$ streptomycin.

An enriched undifferentiated cell pool was achieved by culturing the cells 6 days in selective Neurosphere medium: DMEM/F12 supplemented with some glucose and sodium bicarbonate, $5 \mathrm{mM}$ HEPES, $9.6 \mu \mathrm{g} / \mathrm{mL}$ putrescine, $10 \mu \mathrm{g} / \mathrm{mL}$ ITSS, $0.063 \mu \mathrm{g} / \mathrm{mL}$ progesterone, $2 \mu \mathrm{g} / \mathrm{mL}$ heparin, $20 \mathrm{ng} / \mathrm{mL}$ EGF, $20 \mathrm{ng} / \mathrm{mL}$ bFGF, $1 \mathrm{X}$ penicillin-streptomycin and $2 \%$ B27 supplement without vitamin. Actually, this last medium presents such stringent growing conditions in which only mainly most resistant and undifferentiated cells can survive (leading to the expected enrichment) and so grow under easily identifiable (neuro)sphere organization (Fig.3).
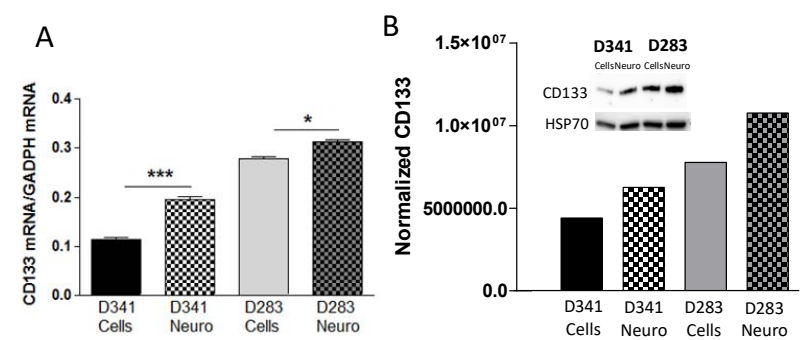

Fig. 2. Comparative analysis of CD133 mRNA and protein expression measured by real time-PCR (A) or Western blot (B) in D341 and D283 MB cell lines, cultured in Normal medium or in Neurosphere medium.

Figure 2 shows a comparative analysis of mRNA level and protein expression of CD133 a typical marker overexpressed in tumor initiating cells and cancerous stem undifferentiated cells [5]. Our results, showing a significant increase of CD133 at both mRNA and protein level, confirm well the undifferentiated cell enrichment after neurosphere assay.

\section{MB CELL DEP HF CROSSOVER FREQUENCY RESULTS}

The same four cell pools, derived from D341 and D383 line cultures characterized in Fig.2, have been studied using our microfluidic DEP sensors. The resulting HF crossover frequencies, measured on an average of 20 cells for each cases, are summarized under box plot chart in Fig.3. One can see that for each line, despite the data showed a relative dispersion of crossover frequencies relying on natural cell heterogeneity occurring in the line, the obtained average DEP signatures still present a clear and significant difference between differentiated and undifferentiated enriched cell pools. We can observe a decrease of HF crossover frequency between lines cultured in Normal \& Neurosphere medium that seems to follow the level of overexpression of specific genes in the cell cytoplasm and so might be well correlated to a given phenotype.

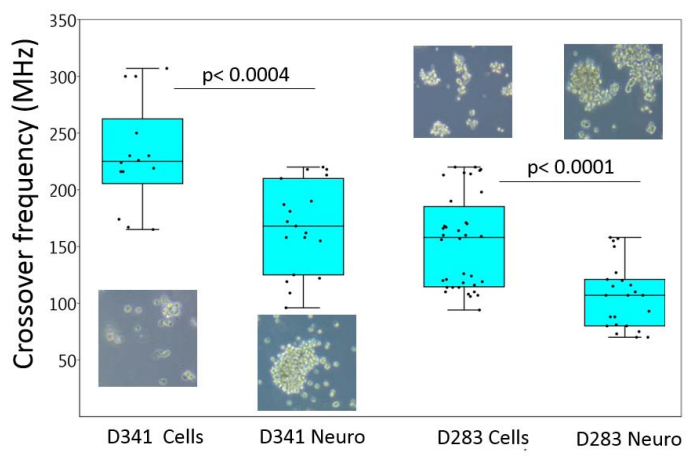

Fig. 3. Significant differences of HF crossover frequencies in D341 \& D283 cells cultured in normal and neurosphere conditions.

\section{CONCLUSION}

We presented an original label-free technique allowing screening the intracellular dielectric properties of cell subpopulations in real time. Differences observed in the HF crossover frequencies between subpopulations presenting biological differences at the functional level, underline a great potential for the development of new methods to characterize and discriminate undifferentiated cancer cells.

\section{ACKNOWLEDGMENT}

This project has received funding from the $\mathrm{H} 2020$ research and innovation program under grant agreement No 737164.

\section{REFERENCES}

[1] Jeon et al., Cancer Res. 2014 Aug 15;74(16):4482

[2] R. Pethig, et al., "Dielectrophoresis: A Review of Applications for Stem Cell Research," Journal of Biomedicine and Biotechnology, vol. 2010.

[3] F. Hjeij et al, "UHF dielectrophoretic handling of individual biological cells using BiCMOS microfluidic RF-sensors", EUMC Conference 2016

[4] R. Manczak et al, "Discrimination of Glioblastoma Cancer Stem Cells by measuring their UHF-DEP Crossover Frequency”, IMBIOC 2018

[5] Li, Zhong. "CD133: A Stem Cell Biomarker and beyond." Experimental Hematology \& Oncology 2 (2013): 17. PMC. Web. 25 June 2018. 